\title{
The effect of $5-\mathrm{HT}_{2 \mathrm{a} / 2 \mathrm{c}}$ receptor agonist microinjected into central amygdaloid nucleus and median preoptic area on maternal aggressive behavior in rats Efeïto sobre o comportamento materno agressivo de ratos da microinjeção do agonista seletivo de receptores $5-\mathrm{HT}_{2 \mathrm{a} / 2 \mathrm{c}}$ no núcleo central da amigdala e na ârea pré-óptica medial
}

\section{Rosa Maria Martins de Almeida, ${ }^{1}$ Marcia Giovenardi, ${ }^{1}$ Simone Perroni da Silva, ${ }^{1}$ Verônica Paz de Oliveira, ${ }^{1}$ Dirson João Stein ${ }^{1}$}

\begin{abstract}
Objective: Much evidence supports the hypothesis that 5-hydroxytryptamine (5-HT) activation is related to the inhibition of aggression. We examined potentially pro- and anti-aggressive effects of the 5-HT ${ }_{2 A / 2 C}$ receptor agonist on specific brain sites. Method: Female Wistar rats on the $7^{\text {th }}$ day postpartum were microinjected with the selective $5-H T_{2 A 2 C}$ receptor agonist, $\alpha-$ methyl-5hydroxytryptamine maleate $(0.2$ to $1.0 \mu \mathrm{g} / 0.2 \mu \mathrm{l})$ into the central amygdaloid nucleus and median preoptic nucleus. For each brain area studied, the frequency of the behaviors: locomotion, social investigation, lateral threat, attacks (frontal and lateral), and biting the intruder were compared among the various treatments by an Analysis of Variance, followed when appropriate, by Tukey's test. Results: Microinjection of the selective 5-HT ${ }_{2 A 2 C}$ receptor agonist, a-methyl-5-hydroxytryptamine maleate into central amygdaloid nucleus increased maternal aggression in the absence of concurrent changes in non-aggressive behavior. By contrast, microinjection of the selective 5-HT ${ }_{2 A 2 C}$ receptor agonist at several dilutions into the median preoptic nucleusdid not alter aggressive behavior. Conclusions: The current and earlier data with pro- and anti-aggressive effects of the 5-HT 2 aarc receptor agonist, when microinjected into the median preoptic nucleus relative to the central amygdaloid nucleus, medial septum and periaqueductal grey area in female rats point to functionally separate serotonin receptor populations in the amygdaloid-septal-hypothalamic and periaqueductal gray matter areas controlling aggressive behavior. It is possible that amygdaloid $5-H T_{2 a / 2 c}$ receptors may increase aggressive behavior in lactating females as a result of changes in fear.
\end{abstract}

Keywords: Serotonin agonist; Behavior, animal; Rats, Wistar; Maternal behavior; Violence

\begin{abstract}
Resumo
Objetivo: Resultados de muitos estudos sustentam a hipótese de que a serotonina (5-HT) está relacionada com a inibição do comportamento agressivo. Foram examinados os efeitos potenciais pró e anti-agressivos do agonista de receptores $5-\mathrm{HT}_{2 A 12 c} \mathrm{em}$ regiões específicas do cérebro. Método: Ratas fêmeas Wistar no sétimo dia pós-parto receberam microinjeções do agonista seletivo de receptores $5-H T_{2 A / 2}$, $\alpha$-methyl-5-hydroxytryptamine maleate $(0,2$ a $1,0 \mu \mathrm{g} / 0,2 \mu \mathrm{l})$, no núcleo central da amigdala e núcleo pré-óptico medial. Para cada área estudada, as freqüências dos comportamentos: locomoção, investigação social, postura de ameaça, ataques (frontal e lateral) e ato de morder um intruso, foram comparadas entre os diferentes tratamentos por uma análise da variância, seguida quando apropriado do teste de Tukey. Resultados: Os resultados mostraram que a microinjeção do agonista seletivo $\alpha$-methyl-5-hydroxytryptamine maleate no núcleo central da amígdala aumentou a agressividade materna, mas não foram encontrados efeitos estatisticamente significativos no comportamento agressivo após a microinjeção do agonista seletivo de receptores 5-HT ${ }_{2 A / 2 C}$ no núcleo pré-óptico medial nas diferentes diluições estudadas. Conclusões: Os dados atuais e prévios sobre os efeitos pró e anti-agressivos do agonista dos receptores $5-H T_{2 a / 2 c}$ quando microinjetado no núcleo pré-óptico medial, em comparação com a microinjeção no núcleo central da amígdala, no septo medial (MS) e substância cinzenta periaqueductal em ratas apontam para populações funcionalmente independentes de receptores na amígdala-septo-hipotálamo e substância cinzenta periaqueductal, que são responsáveis pelo controle do comportamento agressivo. É possível que os receptores $5-H T_{2 a / 2 c} d a$ amígdala possam aumentar o comportamento agressivo das fêmeas lactantes, como resultado de mudanças decorrentes do estado emocional de medo.
\end{abstract}

Descritores: Agonistas de serotonina; Comportamento animal; Ratos Wistar; Comportamento materno; Violência

1 Laboratory of Neurosciences, Health Sciences, Universidade do Vale do Rio dos Sinos (UNISINOS), São Leopoldo (RS), Brazil

Preliminary results of this study were presented at the XV Annual Meeting of the FESBE (2000), Caxambu (MG), Brazil

Financing: UNISINOS (Brazil), The State of Rio Grande do Sul

Research Foundation - FAPERGS (Brazil).

Conflict of interests: None

Submitted: 18 January 2005

Accepted: 9 November 2005

\section{Correspondence}

Rosa M. M. de Almeida

Av. Unisinos 950

93022-000 São Leopoldo, RS, Brazil

E-mail:rmalmeida@unisinos.br 


\section{Introduction}

Clinical and pre-clinical data have pointed to the involvement of brain 5-HT in emotional behaviors ${ }^{1}$ such as aggression ${ }^{2}$ and violent and impulsive behavior. ${ }^{3}$

One model for the study of aggressive behavior in females is maternal aggression, a type of aggression with a substantial fear component. Differently from males, the aggressive behavior of lactating female rats comprises besides the offensive pattern the defensive component. In the lactating female rat, high levels of aggressive behaviors against male and female intruders are displayed during the first 10 days after delivery, and thereafter aggression declines to very low levels. ${ }^{4}$ Surprisingly, in female rats, only a few studies relate aggression to the activity in brain 5 -HT systems. ${ }^{5}$

Among several types of 5 - $\mathrm{HT}$ receptors, stimulation of the $5-\mathrm{HT}_{1 \mathrm{~A}}, 5-\mathrm{HT}_{1 \mathrm{~B}}$ and $5-\mathrm{HT}_{2 \mathrm{~A} / 2 \mathrm{C}}$ receptors has been shown to decrease aggressive behavior in different animal models. ${ }^{6}$ Clinically, the most frequently targeted sites are the $5-\mathrm{HT}_{2 \mathrm{~A}}$ receptors for the management of aggressive outbursts. For example, drugs such as the antipsychotic risperidone effectively reduces aggressive behavior in various patient subgroups.

In addition, the $5-\mathrm{HT}_{2 \mathrm{~A} / 2 \mathrm{C}}$ receptors have been of a particular interest to preclinical research on aggression since low doses of 1-(2,5-dimethoxy-4-iodophenyl)-2-aminopropane (DOI), a $5-\mathrm{HT}_{2 \mathrm{~A} / 2 \mathrm{C}}$ receptor agonist, decrease aggression in a behaviorally specific manner in rats without impairment of motor activity. ${ }^{7}$ Intracerebroventricular (ICV) injections of this $5-\mathrm{HT}_{2}$ receptor agonist (DOI) inhibited maternal aggression without affecting maternal care. $^{8}$ The current studies focus on $\alpha$-Methyl-5hydroxytryptamine maleate, another agonist that shows high affinity for $5-\mathrm{HT}_{2 \mathrm{~A}}$ and $5-\mathrm{HT}_{2 \mathrm{C}}$ receptors $(\mathrm{Ki}=6.1$ and 7.3, respectively). ${ }^{9}$ Brain regions such as the hippocampus, septum, preoptic area, amygdala and dorsal periaqueductal gray matter are rich in $5-\mathrm{HT}_{2 \mathrm{~A} / 2 \mathrm{C}}$ receptors. ${ }^{10}$

Two specific brain sites such as median preoptic nucleus ( $\mathrm{MnPO}$ ) and central amygdaloid nucleus (CeM) which are implicated in the neural control of aggressive behavior and which contain a high density of $5-\mathrm{HT}_{2 \mathrm{~A} / 2 \mathrm{C}}$ receptors were selected as targets for microinjections with the selective agonist $\alpha$-Methyl-5-hydroxytryptamine maleate to assess its effects on maternal aggression.

\section{Method}

\section{Animals}

Female Wistar rats ( $n=59)$, 3-4 months old and weighing between 250-350 g were used. The animals were maintained on an inverted 12:12 light:dark cycle, lights on at 4:00 am. To test for aggressive behavior, male Wistar rats $(n=59)$ were used as a stimulus intruder. On the $4^{\text {th }}$ postpartum day each female was implanted with guide cannulae.

\section{Surgery}

On the $4^{\text {th }}$ postpartum day, the females were anesthetized with sodium thiopental $(50 \mathrm{mg} / \mathrm{kg}$ ) IP), placed in a stereotaxic frame (David Kopf; Tujunga, CA, USA), and implanted with a guide cannula (G30) fixed with dental cement to the skull. A unilateral guide cannula was aimed at $\mathrm{MnPO}: 0.3 \mathrm{~mm}$ anterior to the bregma, $1.0 \mathrm{~mm}$ lateral to the mid-saggital line, $4.0 \mathrm{~mm}$ below the dura mater, and bilateral guide cannulae at CeM: $2.3 \mathrm{~mm}$ posterior to the bregma, $4.0 \mathrm{~mm}$ lateral to the mid-saggital line, $4.6 \mathrm{~mm}$ below the dura mater. All the parameters were based on Stereotaxic Brain Rats Atlas.

Experiments were performed in accordance with the $\mathrm{NIH}$ Guide for Animal Care and Use and they were approved by the Research Committee of the University.

\section{Drugs and injections}

$\alpha$-Methyl-5-hydroxytryptamine maleate, a $5-\mathrm{HT}_{2 \mathrm{~A} / 2 \mathrm{C}}$ receptor agonist (RBI, Natick, MA, USA) was diluted in $0.9 \%$ saline. Each animal received only one injection per brain area of $\alpha$-Methyl-5-hydroxytryptamine maleate $(0.2 ; 0.5$ or $1.0 \mu \mathrm{g})$ or saline. The injection volume was $0.2 \mu \mathrm{l}$.

\section{Behavioral tests}

On the $7^{\text {th }}$ day postpartum, the microinjections were performed and followed by resident-intruder tests. The behavioral recordings began 10 minutes after the injection of either a-Methyl-5-hydroxytryptamine maleate or saline. The naive male intruder was placed into the female's cage and immediately the behaviors were videotaped for $10 \mathrm{~min}$. In the experiments, locomotion and social investigation were used to evaluate the general behavioral capacities of the females, in order to detect possible symptoms of the 5-HT syndrome.

\section{Histological analysis}

After completion of all behavioral tests, the dams were deeply anesthetized with an overdose of sodium thiopental. Brains were perfused with $0.9 \%$ saline solution and thereafter with $10 \%$ formol. They were removed and fixed in $10 \%$ formol and latter cut on a vibratome in 50-micron coronal slices. The slices were placed on gelatinized microcover slides and stained with cresyl violet. Positions of the cannulae tips were determined via microscopic analysis and only the animals with an exact localization were used (50\%, Figures 1 and 2).

\section{Analysis}

The frequency of each behavior was expressed as mean \pm SEM (Standard Error Mean). For each brain area studied, the frequency of the behavioral measures was compared across the various treatments by analysis of variance (ANOVA), followed when appropriate by the Tukey's post-hoc test. In all cases, the alpha level was set at 0.05 .

\section{Results}

When microinjected into $\mathrm{CeM}$, the $5-\mathrm{HT}_{2 \mathrm{~A} / 2 \mathrm{C}}$ receptor agonist $\alpha$-methyl-5-hydroxytryptamine at $0.2 \mu \mathrm{g} / 0.2 \mu \mathrm{l}$, bilaterally, significantly increased the biting response directed toward the intruder when compared to the group treated with saline $[F(3,20)=2.68 ; p=0.05]$. The frequency of attacks against 


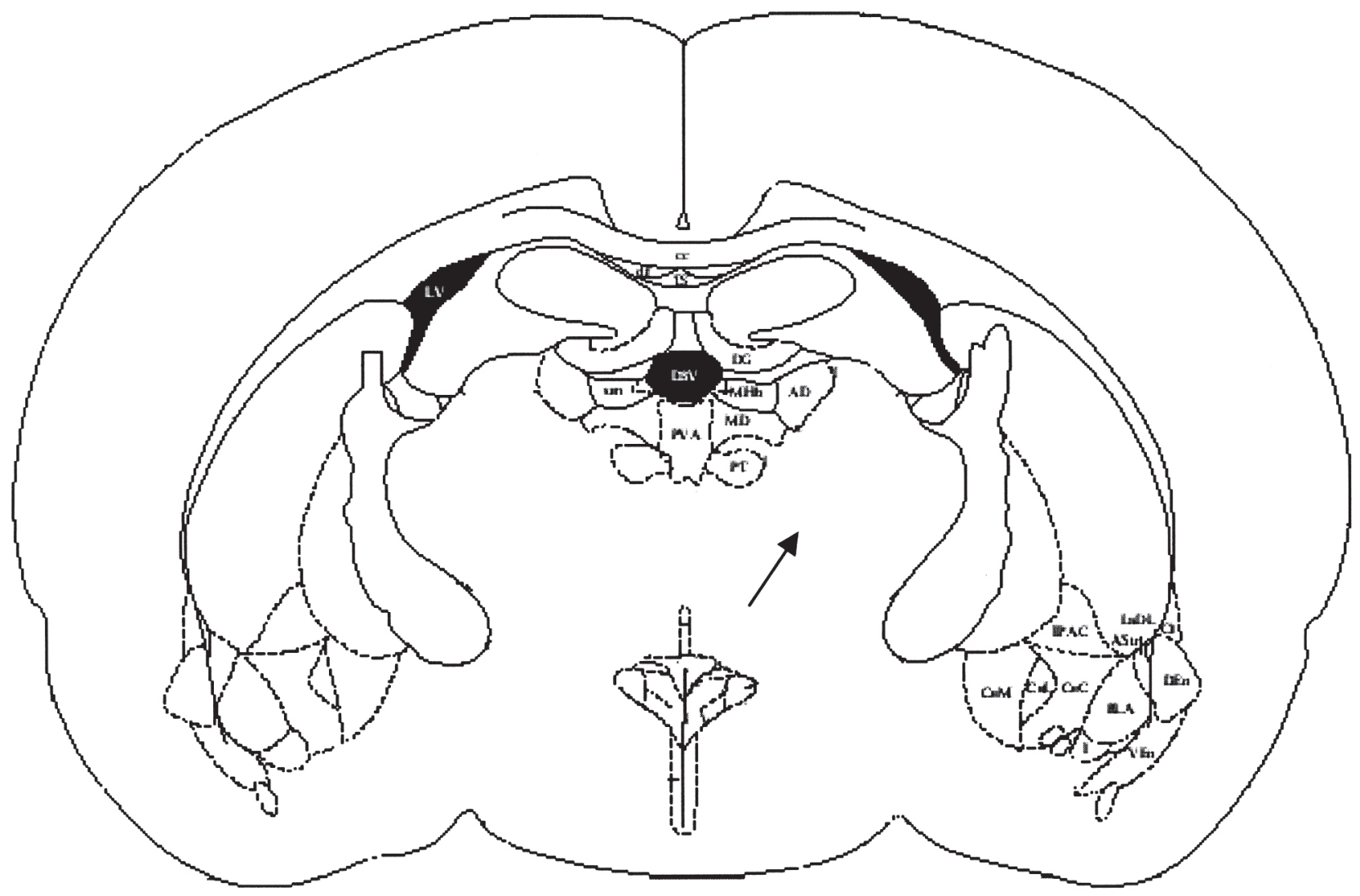

Figure 1 - Schematic representation of coronal section the female rat brain showing the injection sites of saline and/or $\alpha$-Methyl-5hydroxytryptamine maleate (A). Filled circles represent the site of the microinjection into centromedial amygdaloid nuclei (CeM; B). Representative photomicrograph of needle trajectory and microinjection into the CeM (C). Abbreviations: CeL, lateral amygaloid nucleus; CeC, central amygaloid nucleus, caps.

the intruder by the female resident also showed a significant increase across the different dilutions studied (Figure 3). Specifically, the dilution at $0.2 \mu \mathrm{g} / 0.2 \mu \mathrm{l}$ increased attacks when compared to groups treated with $0.5 \mu \mathrm{g} / 0.2 \mu \mathrm{l}$ and $1.0 \mu \mathrm{g} / 0.2 \mu \mathrm{l}[\mathrm{F}(3,20)=3.173 ; \mathrm{p}=0.04]$. The nonaggressive behaviors such as locomotion and social investigation did not show any statistically significant changes across the dilutions studied when compared to the saline group $[F(3,20)=0.219 ; p=0.882$ and $F(3,20)=2.418$; $\mathrm{p}=0.09$; respectively].

Figure also shows the results of $\alpha$-Methyl-5-hydroxytryptamine maleate microinjected into $\mathrm{MnPO}$. In the currently used dilution range, this compound did not change the aggressive behavior towards intruders. Furthermore, the locomotor activity did not undergo any significantly statistical changes when compared to the saline group $[F(3,31)=0.024 ; p=0.995]$. Similarly, the social investigation did not show any significant changes when compared to the saline group $[F(3,31)=0.715$; $p=0.551]$

\section{Discussion}

The key findings of the present studies are the anatomically differentiated effects of the $5-\mathrm{HT}_{2 \mathrm{~A} / 2 \mathrm{C}}$ receptor agonist, $\alpha$-Methyl5-hydroxytryptamine maleate. When injected into CeM, this agonist increased the frequency of attacks by the female resident toward the intruder. However, this compound had no effects on maternal aggressive behavior when it was microinjected into MnPO. The general motor activity in the lactating females and the exploratory activity or social investigation (e.g., sniff the intruder) remained without significant alteration after the administration of $5-\mathrm{HT}_{2 \mathrm{~A} / 2 \mathrm{C}}$ receptor agonist in either brain area.

Previously, we have found that microinjection of the selective $5-\mathrm{HT}_{2 \mathrm{~A} / 2 \mathrm{C}}$ receptor agonist $(0.2$ to $1.0 \mu \mathrm{g} / 0.2 \mu \mathrm{l})$ into dorsal periaqueductal gray matter (DPAG), but not into medial septum, significantly and specifically inhibited aggression, and this inhibitory effect extends to aggression in lactating
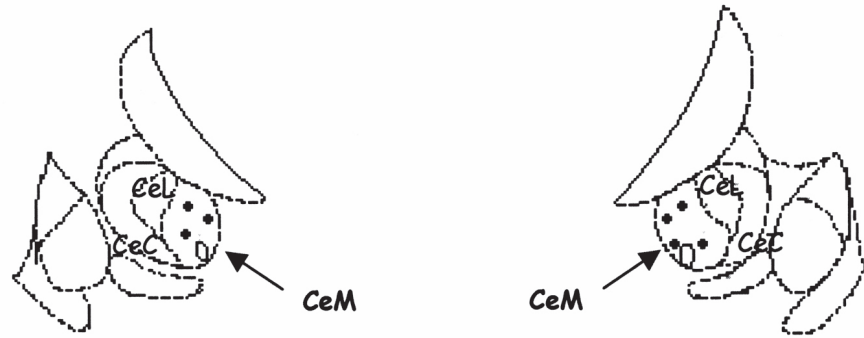

Figure 2 - Schematic representation of coronal section the female rat brain showing the injection sites of saline and/or $\alpha$-Methyl-5hydroxytryptamine maleate (A). Filed circles represent the site of the microinjection into median preoptic area (MnPO; B). Representative photomicrograph of needle trajectory and microinjection into the MnPO (C). 
female rats. ${ }^{11}$ Although binding studies found a higher density of these receptors in limbic areas, it is interesting to note that $\alpha$-Methyl-5-hydroxytryptamine maleate, the $5-\mathrm{HT}_{2 \mathrm{~A} / 2 \mathrm{C}}$ receptor agonist, is more effective in reducing the aggressive behavior in mesencephalic rather than in diencephalic or telencephalic areas. ${ }^{11}$ It is possible that these receptors might have more sensitivity at these dilutions in mesencephalic areas in female rats. Studies with lesions, electrical stimulation and cellular activation via immediate early gene expression have established the $\mathrm{MnPO}$ as an area that is critically involved in maternal behavior ${ }^{12-13}$ and there is evidence for its role in maternal aggressive behavior, particularly in hamsters. The MNPO is a brain region which contains $5-\mathrm{HT}_{2 \mathrm{~A} / 2 \mathrm{C}}$ receptors, but the results from the current experiment suggest that these receptors are less significant in the modulation of maternal aggressive behavior.

It is clear that the behavioral effects of $5-\mathrm{HT}_{2 \mathrm{~A} / 2 \mathrm{C}}$ receptor agonist were related to the dilution studied. It is noteworthy that a specific increase in maternal aggression was seen at a particular dilution of $\alpha$-Methyl-5-hydroxytryptamine maleate when microinjected into the CeM. By contrast, after the microinjection of the lower dilutions, a reduction of the maternal aggression was not seen. The increase in aggressive behavior after amygdaloid microinjections of the $5-\mathrm{HT}_{2 \mathrm{~A} / 2 \mathrm{C}}$ receptor agonist may be due to the modulation of fear processes in the lactating female.

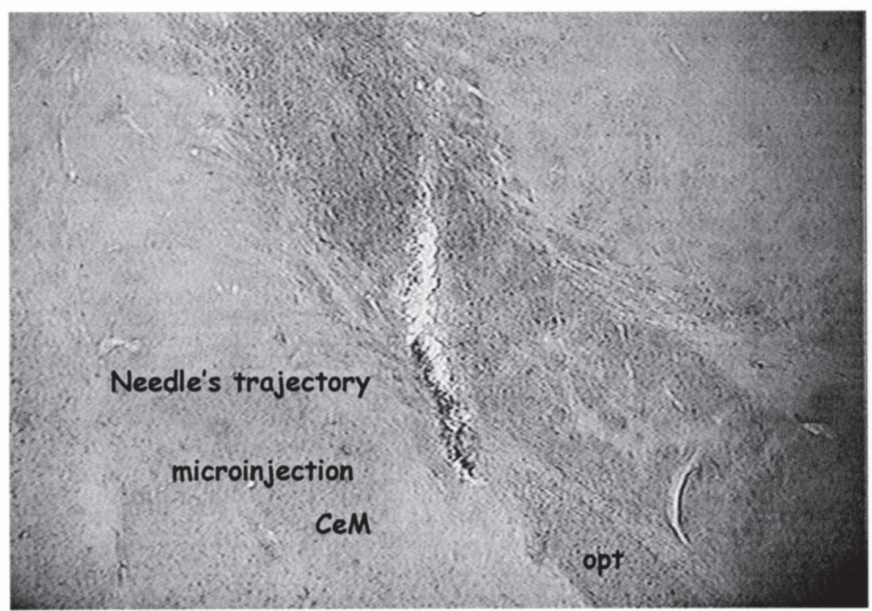

Figure 3 - Effects of $\alpha$-Methyl-5-hydroxytryptamine maleate and/ or saline microinjected into the medial preoptic nucleus (MnPO) and the central amygdaloid nucleus (CeM) a dose range of $0.2-1.0 \mu \mathrm{g} / 0.2 \mu \mathrm{l}$ on the mean frequency \pm SEM of lateral threat, attacks and bite during a 10-min test against a male intruder by lactating female rat. In all figures $\mathbf{n}$ indicates the number of animals in each group and in cases. Indicates significant difference compard to $0.5 \mu \mathrm{g}$ group; " indicates significant diffence compared to $1.0 \mu \mathrm{g}$ group

Previously, we have found that the anti-aggressive effects of $5-\mathrm{HT}_{2 \mathrm{~A} / 2 \mathrm{C}}$ receptor agonist were highly effective when injected into the dorsal periaqueductal gray matter as compared to the septal structure. It is also important to note that periaqueductal gray matter is proposed as the final efferent structure that organizes aggressive behavior. Electric stimulation of DPAG leads to a chain of events collectively named the defense reaction. ${ }^{14}$

There are reciprocal pathways that connect the DPAG to the amygdala. The amygdala-periaqueductal gray system is considered as an important anatomical substrate for autonomic responses of emotional behaviors. ${ }^{15}$ Both structures constitute the so-called aversion system with stimulatory functions for aggressive behaviors. Parts of the amygdala seem to integrate environmental stimuli, and this information is conveyed to the periaqueductal gray matter where the degree of threat of those stimuli is processed. ${ }^{14}$ In the DPAG, it can be conceived that the aversive nature is integrated and aggressive behavior is organized. The DPAG has been hypothesized to assume an integrative role that is responsible for organizing the final response, in the present case to generate aggressive behavior. ${ }^{5}$ In conclusion, the $5-\mathrm{HT}_{2 \mathrm{a} / 2 \mathrm{c}}$ receptor agonist, $\alpha$-Methyl-5hydroxytryptamine maleate, microinjected into $\mathrm{CeM}$ at the specific dilution $0.2 \mu \mathrm{g} / 0.2 \mu \mathrm{l}$ promotes aggressive behavior relative to the groups treated with the higher dilutions of the drug dose. Microinjections into MnPO in female rats caused no effect on maternal aggression.

\section{Acknowledgments}

We thank Dr. Klaus A. Miczek (Tufts University) for revising the text and for all suggestions to improve this article. SPdaS and VPdeO were supported by fellowships from UNISINOS.

References

1. Iversen SD. 5-HT and anxiety. Neuropharmacology. 1984;23(12B): 1553-60.

2. Miczek KA, Donat P. Brain 5-HT system and inhibition of aggressive behaviour. In: Bevan P, Cools AR, Archer T, eds. Behavioral pharmacology of 5-HT. New Jersey: Lawrence Erlbaum Associates; 1989. Section III:117-48.

3. Coccaro EF. Central serotonin and impulsive aggression. $\mathrm{Br} \mathrm{J}$ Psychiatry Suppl. 1989;155(8):52-62.

4. Giovenardi M, Padoin MJ, Cadore LP, Lucion AB. Hypothalamic paraventricular nucleus modulates maternal aggression in rats: effects of ibotenic acid lesion and oxytocin antisense. Physiol Behav. 1998;63(3):351-9.

5. De Almeida RM, Lucion AB. 8-OH-DPAT in the median raphe, dorsal periaqueductal gray and corticomedial amygdala nucleus decreases, but the medial septal area it can increase maternal aggressive behavior in rats. Psychopharmacology. 1997;134:392-400.

6. Olivier B, Mos J, Tulp MThM, van der Poel AM. Animal models of anxiety and aggression in the study of serotonergic agents. In: Langer SZ, Brunello N, Racagni G, Mendlewicz, eds. Serotonin receptor subtypes: pharmacological significance and clinical implications. 1992. p. 67-79.

7. Albonetti ME, Gonzalez MI, Wilson CA, Farabollini F. Effects of neonatal treatment with 1-(2,5-dimethoxy-4-iodophenyl)-2 aminopropane $\mathrm{HCL}(\mathrm{DOI})$ and ritanserin on agonistic behavior in adult male and female rats. Aggress Behav. 1994;20:235-42.

8. Virkkunen M, Kallio E, Rawlings R, Tokola R, Poland RE, Guidotti A, Nemeroff C, Bissette G, Kalogeras K, Karonen SL. . Personality profiles and state aggressiveness in Finnish alcoholic, violent offenders, fire setters, and healthy volunteers. Arch Gen Psychiatr. 1994;51(1):28-33. 
9. Baxter G, Kennett G, Blaney F, Blackburn T. 5-HT 2 receptors subtypes: a family re-united? Trends Pharmacol Sci. 1995;16(3):105-10.

10. Radja F, Daval G, Hamon M, Verge D. Pharmacological and physicochemical properties of pre-versus postsynaptic 5hydroxytryptamine $1 \mathrm{~A}$ receptor binding sites in the rat brain: a quantitative autoradiographic study. J Neurochem. 1992;58(4):1338-46.

11. De Almeida RM, Giovenardi M, da Silva SP, de Oliveira VP, Stein DJ. Maternal aggression in Wistar rats: effects of $5-\mathrm{HT}_{2 \mathrm{~A} / 2 \mathrm{C}}$ receptor agonist and antagonist microinjection into dorsal periaqueductal gray matter and medial septum. Braz J Med Biol Res. 2005;38(4):597-602.

12. Lonstein JS, Gammie SC. Sensory, hormonal, and neural control of maternal aggression in laboratory rodents. Neurosci Biobehav Rev. 2002;26(8):869-88.

13. Numan M, Numan MJ, Schwarz JM, Neuner CM, Flood TF, Smith $\mathrm{CD}$. Medial preoptic area interactions with the nucleus accumbensventral pallidum circuit and maternal behavior in rats. Behav Brain Res. 2005;158(1):53-68.

14. Fanselow MS. The midbrain periaqueductal gray as a coordinator of action in response to fear and anxiety. In: Depaulis A, Bandler R, eds. The midbrain periaqueductal gray matter: functional, anatomical, and neurochemical organization. New York: Plenum Press; 1991. p.151-73.

15. Bandler R, Shipley MT. Columnar organization in the midbrain brain periaqueductal gray: modulates for emotional expression? Trends Neurosci. 1994;17(9):379-89. Erratum in: Trends Neurosci. 1994;17(11):445. 